\title{
Improved Crack Closure Line Position: An Im- proved Model for Crack Breathing Phenomenon
}

\author{
R. Ramezanpour, M. Ghayour and S. Ziaei-Rad \\ Department of Mechanical Engineering, Isfahan University of Technology 84156-83111 Isfahan, Iran
}

(Received 3 October 2012; accepted 15 November 2013)

The dynamic behaviour of a cracked Jeffcott rotor is investigated in this paper. The crack is located at the midpoint of the rotor. It is known that when the static deflection dominates the vibration of the rotating shaft, the crack opens and closes according to the shaft rotation. This phenomenon is known as crack breathing. There are several models for classifying crack breathing phenomena, such as the switching crack model, harmonic approach model, and response-dependent breathing crack model. In order to model the breathing of the crack in the responsedependent breathing crack model, the concept of a crack closure line position (CCLP) is proposed and used by some researchers. The main scope of this work is to present an improved crack closure line position (ICCLP). By using several contour plots over the crack's surface, it is shown that the imaginary line that separates the open and closed parts of a breathing crack should not be considered perpendicular to the crack tip. It is also shown that the improved model positively agrees with those proposed in the literature. The effects of ICCLP on the coefficients of the local flexibility matrix are investigated.

\section{NOMENCLATURE}

\begin{tabular}{|c|c|c|}
\hline $\begin{array}{l}\text { Symb. } \\
I\end{array}$ & $\begin{array}{l}\text { Unit } \\
\mathrm{m}^{4}\end{array}$ & $\begin{array}{l}\text { Description } \\
\text { area moment of inertia for the } \\
\text { cross section }\end{array}$ \\
\hline $\begin{array}{l}k_{i j} \\
d p\end{array}$ & $\begin{array}{l}\mathrm{N} / \mathrm{m}, \mathrm{N} / \mathrm{rad} \\
\mathrm{m}\end{array}$ & $\begin{array}{l}\text { cross-coupled stiffness } \\
\text { disk diameter }\end{array}$ \\
\hline$e$ & $\mathrm{~m}$ & eccentricity \\
\hline$[k]_{g}$ & & global stiffness matrix \\
\hline$\varphi$ & rad & initial phase angle \\
\hline$[c]_{l}$ & & $\begin{array}{l}\text { local flexibility matrix of the } \\
\text { cracked shaft }\end{array}$ \\
\hline$m$ & $\mathrm{~kg}$ & mass of the disk \\
\hline$\nu$ & & Poisson ratio \\
\hline$R, d$ & $\mathrm{~m}$ & $\begin{array}{l}\text { radius and diameter of the shaft, } \\
\text { respectively }\end{array}$ \\
\hline$\alpha$ & $\mathrm{rad}$ & $\begin{array}{l}\text { rotor center displacement in } \\
\text { rotational direction }\end{array}$ \\
\hline$l$ & $\mathrm{~m}$ & shaft length \\
\hline$k_{x}$ & $\mathrm{~N} / \mathrm{m}$ & stiffness in $x$ direction \\
\hline$k_{y}$ & $\mathrm{~N} / \mathrm{m}$ & stiffness in $y$ direction \\
\hline$k_{u}$ & $\mathrm{~N} / \mathrm{m}$ & stiffness in longitudinal direction \\
\hline$k_{T}$ & $\mathrm{~N} / \mathrm{rad}$ & stiffness in torsional direction \\
\hline$W$ & $\mathrm{Nm}$ & strain energy due to crack \\
\hline$U$ & $\mathrm{Nm}$ & strain energy of uncracked shaft \\
\hline$t$ & $\mathrm{~s}$ & time in seconds \\
\hline$\left[C_{s}\right]$ & & $\begin{array}{l}\text { total flexibility matrix of the } \\
\text { uncracked shaft }\end{array}$ \\
\hline$[K]_{l}$ & & local stiffness matrix \\
\hline$\eta_{0}$ & $\mathrm{~m}$ & $\begin{array}{l}\text { location of elemental strip along } \eta^{\prime} \\
\text { direction }\end{array}$ \\
\hline$[H]$ & & transformation matrix \\
\hline$h$ & $\mathrm{~m}$ & height of the element strip \\
\hline$J_{p}$ & $\mathrm{~m}^{2}$ & $\begin{array}{l}\text { polar moment of inertia for the } \\
\text { cross section }\end{array}$ \\
\hline$q_{1}$ & $\mathrm{~N}$ & $\begin{array}{l}\text { longitudinal force (internal } \\
\text { reaction) }\end{array}$ \\
\hline$c$ & $\mathrm{Ns} / \mathrm{m}$ & transversal damping coefficient \\
\hline
\end{tabular}

\begin{tabular}{|c|c|c|}
\hline$E$ & $\mathrm{~N} / \mathrm{m}^{2}$ & modulus of elasticity \\
\hline$q_{4}, q_{5}$ & $\mathrm{Nm}$ & $\begin{array}{l}\text { bending moments (internal } \\
\text { reactions) }\end{array}$ \\
\hline$c_{T}$ & Ns/rad & torsional damping coefficient \\
\hline$\gamma$ & $\mathrm{m}$ & crack depth \\
\hline$\Omega$ & $\mathrm{rpm}$ & revolutionary speed \\
\hline$c_{u}$ & $\mathrm{Ns} / \mathrm{m}$ & longitudinal damping coefficient \\
\hline$M(t)$ & $\mathrm{Nm}$ & external torsional excitation \\
\hline$G$ & $\mathrm{~N} / \mathrm{m}^{2}$ & modulus of rigidity \\
\hline$\omega_{T}$ & $\mathrm{rpm}$ & torsional excitation frequency \\
\hline$A$ & $\mathrm{~m}^{2}$ & cross sectional area of the crack \\
\hline$x, y$ & $\mathrm{~m}$ & $\begin{array}{l}\text { transversal displacements of } \\
\text { center of disk }\end{array}$ \\
\hline$u$ & $\mathrm{~m}$ & $\begin{array}{l}\text { longitudinal displacement of } \\
\text { center of disk }\end{array}$ \\
\hline$\alpha$ & $\mathrm{rad}$ & $\begin{array}{l}\text { torsional displacement of center } \\
\text { of disk }\end{array}$ \\
\hline$F_{z}$ & $\mathrm{~N}$ & longitudinal force (external load) \\
\hline$T$ & $\mathrm{Nm}$ & torsional moment \\
\hline$J$ & $\mathrm{kgm}^{2}$ & $\begin{array}{l}\text { mass moment of inertia of the } \\
\text { disk }\end{array}$ \\
\hline$K_{\mathrm{I}}^{i}$ & $\mathrm{~N} / \mathrm{m} \sqrt{\mathrm{m}}$ & $\begin{array}{l}\text { opening mode of the crack due } \\
\text { to internal load " } i \text { " }\end{array}$ \\
\hline$K_{\mathrm{III}}^{j}$ & $\mathrm{~N} / \mathrm{m} \sqrt{\mathrm{m}}$ & $\begin{array}{l}\text { tearing mode of the crack due to } \\
\text { internal load " } j "\end{array}$ \\
\hline$K_{\mathrm{I}}$ & $\mathrm{N} / \mathrm{m} \sqrt{\mathrm{m}}$ & total opening mode of the crack \\
\hline $\begin{array}{l}K_{\text {III }} \\
F_{1}, F_{2}, F_{\text {III }}\end{array}$ & $\mathrm{N} / \mathrm{m} \sqrt{\mathrm{m}}$ & $\begin{array}{l}\text { total tearing mode of the crack } \\
\text { influential functions }\end{array}$ \\
\hline
\end{tabular}

\section{INTRODUCTION}

Many investigations have been conducted concerning the overall behaviour of cracked shafts in past decades. In general, a crack in rotating shafts may be classified in three different ways: opened crack, closed crack, and breathing crack. In other words, if a cracked shaft rotates under external loading, then the crack opens and closes regularly per revolution, which could be said to breathe. This phenomenon is produced 